\title{
Grape-pressings from northern Greece: the earliest wine in the Aegean?
}

\author{
S.M. Valamoti ${ }^{1}$, M. Mangafa ${ }^{2}$, Ch. Koukouli-Chrysanthaki ${ }^{3}$ \\ $\&$ D. Malamidou ${ }^{4}$
}

Houses burnt down at the Neolithic site of Dikili Tash in northern Greece preserved the remains of wild grapes and figs. The charred shapes showed that there was a pile of grape pips with skinsclear evidence for the extraction of juice. The authors argue that the juice was probably used to make wine - towards the end of the fifth millennium BC the earliest so far from the Aegean. The occupants of the houses also had two-handled cups, providing another clue to consumption of a special kind.

Keywords: Aegean, Macedonia, Greece, wine, grapes, viticulture

\section{Introduction}

The significance of the grape and its products, mainly wine, for prehistoric societies in the Aegean, in particular those of the Bronze Age, has been widely emphasised in the archaeological literature. Both Renfrew (1972) and Gilman (1981) considered viticulture as a key factor in the emergence of Bronze Age elites. For Renfrew, viticulture (together with the cultivation of the olive) allowed the cultivation of marginal land, thus generating the need for a redistributive centre. According to Gilman, the high demands of viticulture tied people to the land and rendered them more vulnerable to control. The product of viticulture, wine, due to its intoxicating, mind-altering properties could have constituted a very special 'food substance', a 'diet enhancer' (Sherratt 1999), which could have been used in special social contexts of consumption (Sherratt 1987), feasting in particular (Dietler 2001). Thus wine represents a substance that could have been involved in the negotiation of power (Hamilakis 1996) and the maintenance of social cohesion in the Aegean (Andreou 2003). The significance of the consumption of a drink, most likely wine, in feasting contexts among Late Bronze Age societies in the Aegean, is emphasised in recent work on the 'Mycenaean Feast' (Wright 2004). The recognition of wine in the archaeological record is therefore of major significance.

One method that has been employed for the detection of wine is the chemical analysis of pottery residues. The identification of tartaric acid (Singleton 1995) in pots is a potential indicator for a grape-based alcoholic beverage. Finds of tartaric acid in vessels from Hajji Firuz Tepe in Iran, dating to the sixth millennium BC (5400-5000 BC, McGovern et al.

\footnotetext{
1 Department of Archaeology, Aristotle University of Thessaloniki, 54124 Thessaloniki, Greece (Email: sval@hist.auth.gr)

2 Archaeologist/Archaeobotanist (deceased 1998)

3 Honorary Curator of Antiquities, Archaeological Museum of Kavala, Greece (Email: ckoukouli@yahoo.gr)

4 Curator of Antiquities, Archaeological Museum of Kavala, Greece (Email: d.malamidou@free.fr)
} 


\section{S.M. Valamoti et al.}

1996), and from Godin Tepe at a later date in the same region, have been interpreted as the remains of 'wine', a conclusion corroborated by the study of pottery shapes (McGovern \& Mitchel 1995). Residue analysis from the Aegean has identified 'wine' by the end of the third millennium BC (Early Bronze Age) in vessels from Crete (Tzedakis \& Martlew 1999: 145).

Other means employed to infer the use of wine by prehistoric societies include the study of the remains of the grape-vine found at archaeological sites (Renfrew 1973) and the recognition of its cultivation through the identification of morphologically domesticated grape pips (Renfrew 1995; 2003). Nevertheless, the association between morphologically domesticated grape-pips with grape cultivation and wine production is not without its problems. At what point in the process of the exploitation of the grapevine a change in morphology of the grape pips took place remains unknown; therefore the possibility that morphologically wild pips could have derived from cultivated vines and that wine was made of wild grapes cannot be excluded (Rivera Nunez \& Walker 1989). The archaeobotanical evidence from Greece has led to the suggestion that there was a 'transitional' phase during which the grape pips were neither wild nor domesticated in their entirety (Logothetis 1974; Renfrew 1995).

A more direct contribution of the archaeobotanical evidence consists of the remains of grape juice extraction per se. These finds consist of grape-skins occasionally attached to grape-pips. Such finds are reported from the end of the third millennium at Myrtos in Crete (Renfrew, J. 1972), tentatively identified as such, and from the end of the second millennium (Late Bronze Age) at Toumba, Thessalonikis, here experimentally shown to represent wine pressings (Mangafa et al. 1998).

This paper presents archaeobotanical remains that prove the deliberate use of grape juice, possibly for the production of a fermented beverage, and most probably some form of wine. Dating from the end of the fifth millennium BC, this can be claimed as the earliest occurrence of wine in the Aegean.

\section{Charred wine-pressings from Dikili Tash}

Dikili Tash/Philippoi (Figure 1) is a tell-site situated in the Drama plain in eastern Macedonia, northern Greece (Koukouli et al. 1997). The grape-finds discussed here represent part of the charred plant remains from the site, retrieved by flotation (French 1971) of soil samples. The archaeobotanical samples from Dikili Tash originate from four Late Neolithic houses destroyed by fire in a major conflagration episode dated to the second half of the fifth millennium BC. The houses were rectangular and parallel to each other, with post-framed walls. They contained ovens, hearths, storage bins, pots and a wide variety of objects related to daily activities. Besides the grape finds (Vitis vinifera L.), the archaeobotanical assemblage from the site consists of cereal grain, pulse seed, fruits and nuts, stored within the houses including the following species: einkorn wheat (Triticum monococcum L.), barley (Hordeum vulgare hexastichum L. var. nudum), lentils (Lens sp.), grass pea (Lathyrus sativus L.), figs (Ficus carica L.), wild pear (Pyrus sp.) and acorns (Quercus sp.) (Valamoti 2004).

The remains of the grapes originate from the floor debris of one of the Late Neolithic Houses, House 1, (several grape pips were also retrieved from earlier excavations at Dikili Tash, published in Renfrew 2003). The grape pips have been directly dated to 4460-4000 BC 


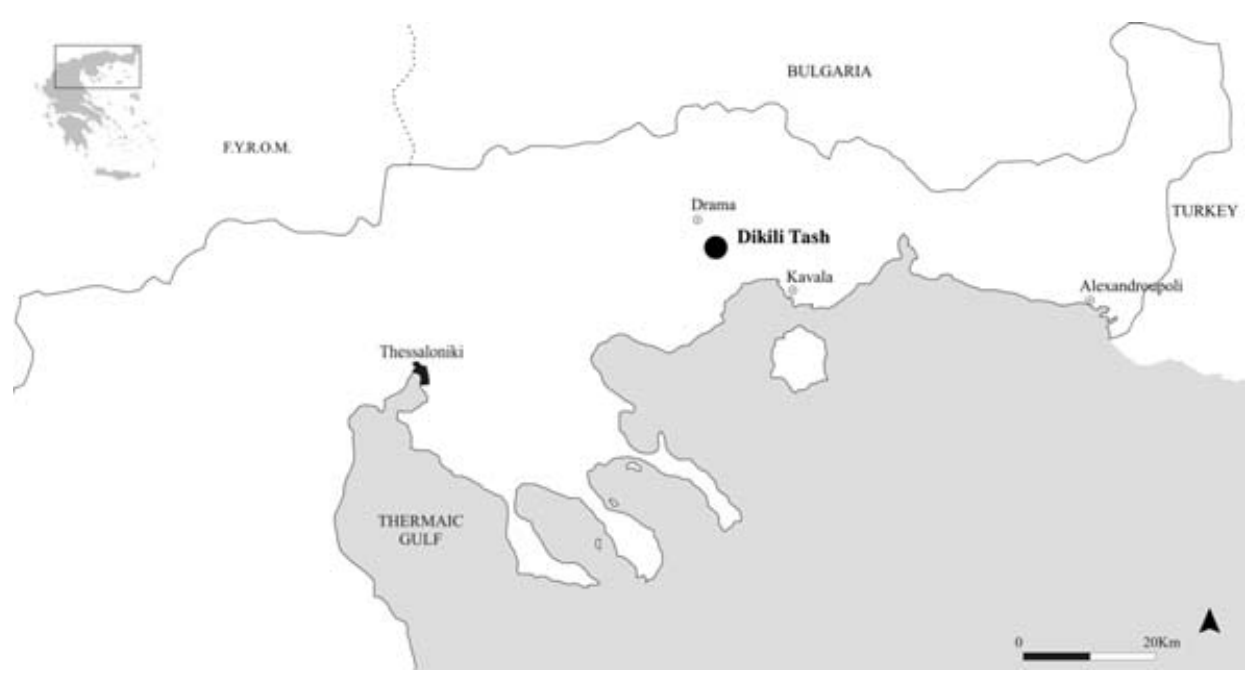

Figure 1. Map of northern Greece indicating location of Dikili Tash.

(N.C.S.R. Demokritos, Laboratory of Archaeometry (Y. Maniatis, G. Fakorellis), sample DEM 179; calibrated following Stuiver \& Reimer 1993, Stuiver et al. 1998). They originate from the southern area of the house and consist of a total of 2460 grape pips and a large number (more than 300) of empty, pressed grape skins occasionally attached to grape pips (Figures $2 \& 3$ ). Measurements carried out on the grape pips from House 1 at Dikili Tash suggest that the grapes used at the site were morphologically wild (Mangafa \& Kotsakis 1996). Two possibilities seem plausible for the House 1, Dikili Tash grapes: they were either harvested from wild plants or they originated from plants at a very early stage of tending or cultivation (before the development of pips bearing the morphological characteristics of domestication). The region of the Drama plain is within the geographical distribution of the wild vine, $V$. vinifera sylvestris (Logothetis 1962) and has been detected in pollen profiles from the Drama plain, in the vicinity of Dikili Tash, between 13000-10000 BP (Wijmstra 1969). Grape pollen has been found in various locations in northern Greece with an increasing, but spatially and temporally discontinuous, presence since the beginning of the Holocene. There is a significant rise from 3500 BP onwards, the increase being related to human activity and the cultivation of the grape vine (Bottema 1982).

The most interesting feature of this grape concentration is the presence of grape skin attached to grape pips, and of loose grape skins (Figure 3). Experimental charring of fresh grapes, raisins and waste products of wine production, i.e. 'wine-pressings' (tsipoura or stemphyla in Greek), indicated that modern wine pressings, when charred at temperatures of the range that would yield charred remains similar to those found at archaeological sites, preserve the original morphological characteristics prior to charring, i.e. pips surrounded by skins and loose skins, and are morphologically distinct from charred raisins and fresh grapes (Mangafa et al. 1998). On the basis of this experiment, the archaeological remains of grapes from Dikili Tash morphologically resemble 'wine-pressings' and could not have originated from charred grapes or raisins. We can therefore conclude with some certainty that the 
S.M. Valamoti et al.
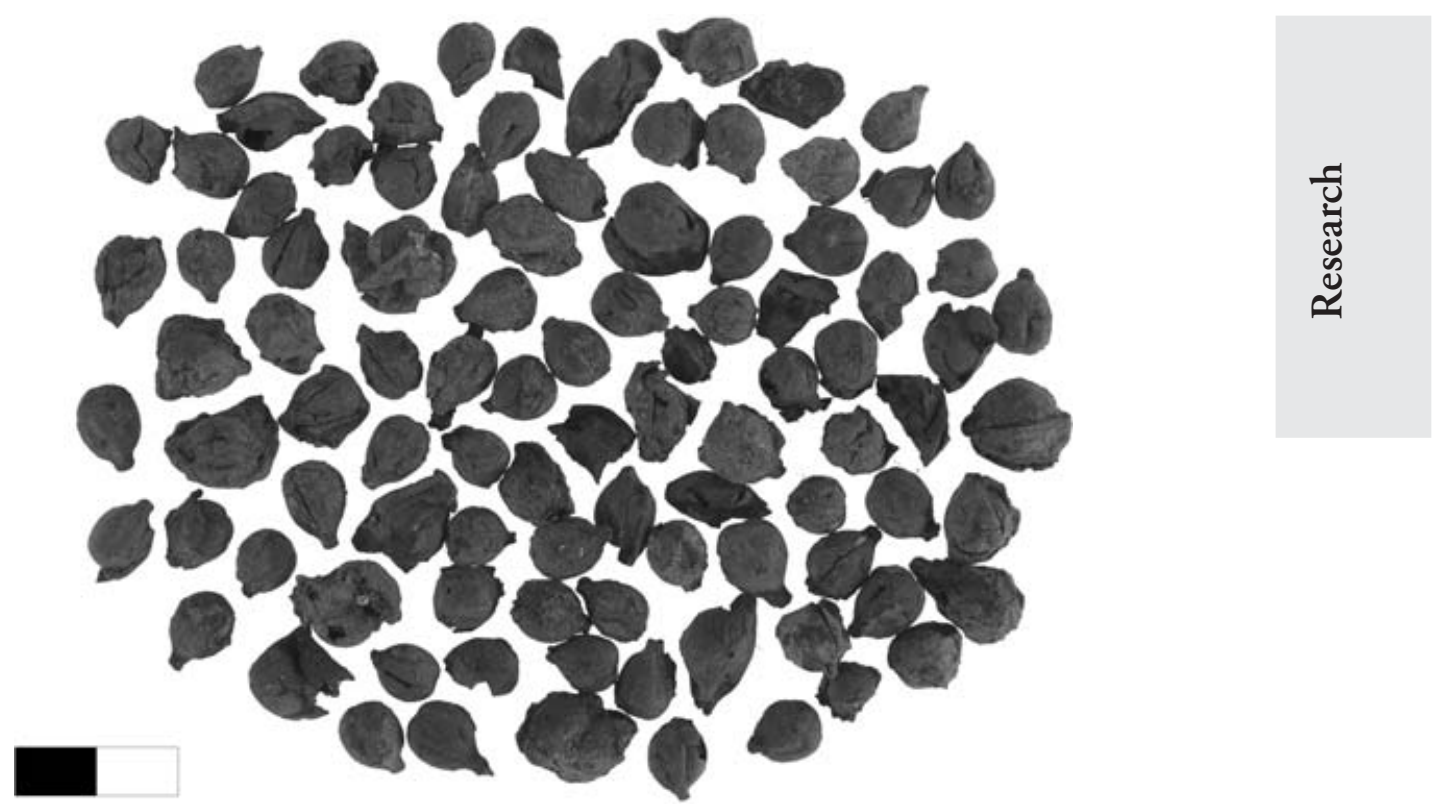

Figure 2. Charred grape pips and 'wine-pressings' from Late Neolithic Dikili Tash (scale: $1 \mathrm{~cm}$ ).
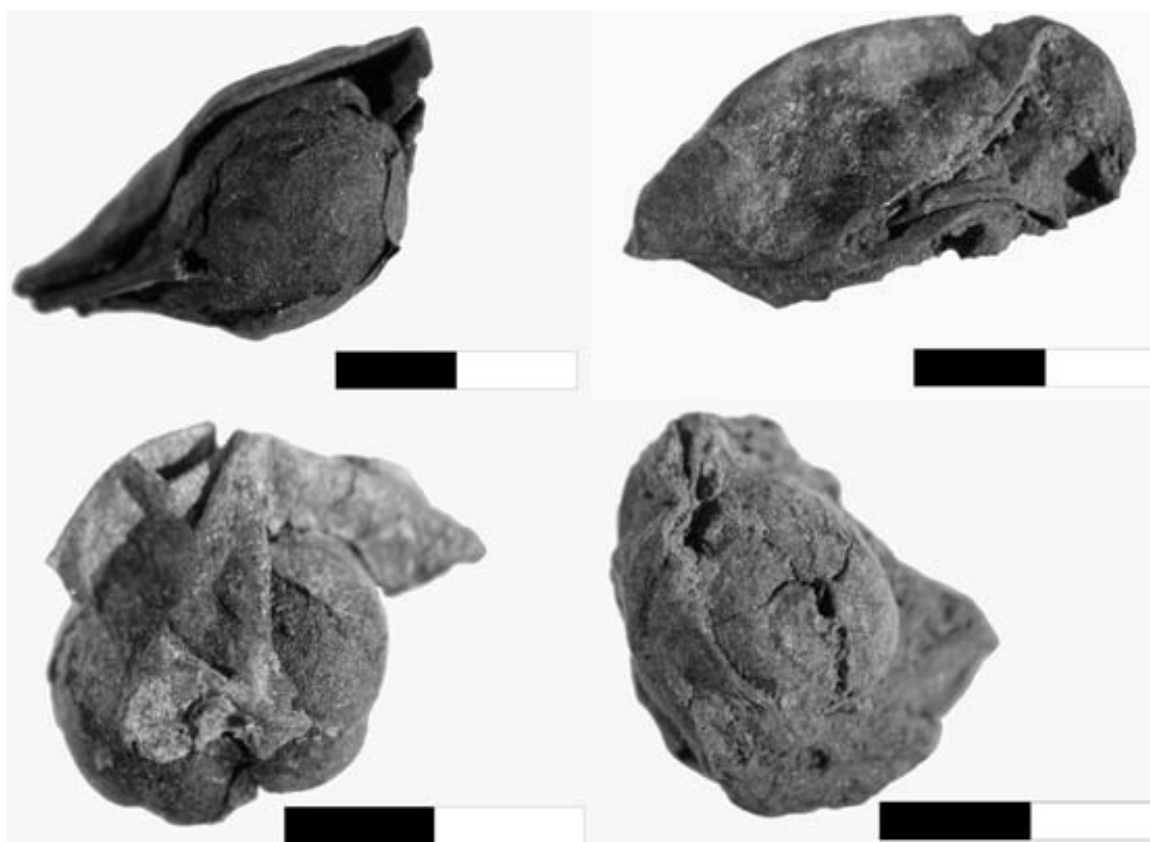

Figure 3. Charred 'wine pressings' from Late Neolithic Dikili Tash (detail of four specimens; scale: $5 \mathrm{~mm}$ ). 
concentration of grapes found at Dikili Tash represents the by-products of extracting juice from grapes.

The high number of pips as well as the homogeneous composition of the sample implies a process of deliberate concentration of grape flesh or juice. Their location in the house could be related to the storage of the by-products for use as animal fodder or preservative (Foxhall 1998). Alternatively they could represent the actual grape juice with the wine pressings, kept perhaps in a wooden or leather container that did not survive the destruction by fire.

\section{Discussion}

The Dikili Tash finds suggest that juice from morphologically wild grapes was being extracted at the end of the fifth millennium BC. Although the end product may well have been wine, we should begin by considering more immediate uses of the juice. Grape juice or must (moustos in Greek), is traditionally used in modern Greece for the preparation of sweets, mixed for example with flour. It is also transformed by boiling to a condensed syrup called petimezi, occasionally mixed with ash and used as a sweetener in various recipes. Such products made of 'boiled down' must are mentioned by ancient Greek and Roman writers and prepared in modern Turkey (Gorny 1995). There is no reason to exclude such uses for the Dikili Tash grapes.

The production of wine, however, is also probable. If this were the case, the remains of 'wine-pressings' could have been contained within a wooden vessel where fermentation could have been under way. These pressings give colour but also a bitter taste to wine as they are rich in tannins (Singleton 1995); therefore they could not have been left with the juice for a long time.

What would the taste of this fruit juice or wine have been like? This is partly dependant on the type of grapes used, i.e. whether they belonged to the wild (Vitis vinifera sylvestris) or domesticated (Vitis vinifera vinifera) variety. Wild grapes are known to have a bitter taste, low in sugar with a skin rich in tannins, yet they can be used to make wine (Singleton 1995). Whichever form of grapevine was used by the Dikili Tash inhabitants, it must have produced enough to make the extraction of juice worthwhile. The use of wild grapes for the production of wine is a strong possibility and it could have been rendered sweet with the addition of honey (Palmer 1995; Gorny 1995) or perhaps sweet fruits like figs. Whole figs were also found charred in the Dikili Tash houses, therefore all the ingredients for the production of an alcoholic beverage were available. In fact, it might have made more sense to produce a fermented beverage rather than a syrup had the grapes been of the bitter wild form. On the other hand, there is no reason to assume that Neolithic fermented beverages and other foodstuffs need be agreeable to our modern taste, addicted as it is to sweet things (Sherratt 1995).

The grape pips and wine-pressings from Dikili Tash, suggest that the use of grapes for the production of wine could have started irrespective of whether the plant had been domesticated or not, and that therefore viticulture is not a prerequisite for wine production. This point has been raised by McGovern (1995) and Singleton (1995) but it has not been possible to demonstrate it on the basis of archaeological finds: tartaric acid is present in both wild and domesticated grapes, therefore chemical analysis cannot 
show whether juice/wine from wild or domesticated grapes was included in the vessels where tartaric acid has been found. Secondly the finds lend support to earlier views that wine production, viticulture and the domestication of the grape vine could have taken place independently in various parts within the broad region of the grape vine's natural distribution, northern Greece being one of them, rather than in one region such as the Near East (Zohary 1995) and Anatolia or the Caspian (Olmo 1995). The assemblage from the Neolithic houses of Dikili Tash includes two-handled cups and jars that suggest a use for decanting and consuming liquids (Figure 4). Later on, the pottery evidence during the third millennium BC
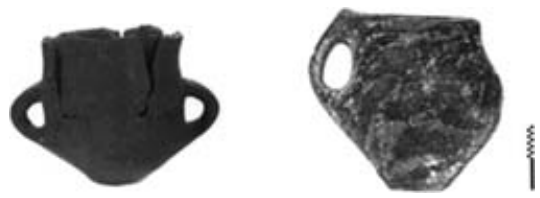

Figure 4. Cups from Final Neolithic Dikili Tash: a) twohandled cup from House 1 (height: $16 \mathrm{~cm}$ ), b) one-handled cup from House 4 (scale: $2 \mathrm{~cm}$ ). from Sitagroi V (Renfrew 1986: pl. XXII, $1,2)$, in the same broad region as Dikili Tash, as well as evidence from other sites, indicates a widespread use of such cups, implying the consumption of some form of beverage. An early consumption of fermented beverages since the beginning of the Neolithic has been argued by Whittle (1996). In light of these arguments, the cups with personified decorations that were deposited during or after large scale feasting, recently recognised at Makriyalos in northern Greece and dating to the first half of the fifth millennium BC (Pappa et al. 2004), call for a content worthy of the circumstances, perhaps wine.

\section{Conclusion}

This find from Dikili Tash represents the earliest evidence for the use of grape juice and/or wine in the Aegean, and the eastern Mediterranean in general, during the Neolithic period. The question of whether wine was indeed produced from the juice extracted from the Dikili Tash grapes remains open, yet the archaeobotanical evidence from the site is as good as the evidence from chemical analysis of pottery residues. Neither the presence of tartaric acid in pottery residues (cf. McGovern \& Mitchel 1995), nor of 'wine pressings' in archaeological deposits, such as those found at Dikili Tash, can definitively prove that the grape product in question was indeed wine. Nevertheless, some support for the production of fermented beverages based on grapes is provided by the pottery cups.

The Dikili Tash finds predate by nearly one millennium the recently announced find of the earliest remains of wine from the site of Erimi in Cyprus by Maria Rosaria Belgiorno (2005). The remains of grape-juice extraction from Late Neolithic Dikili Tash in eastern Macedonia, northern Greece, provide the best and oldest indication, so far, for the production of an alcoholic beverage based on grapes, i.e. some form of wine, in the Aegean during the second half of the fifth millennium BC.

\section{Acknowledgments}

The authors would like to thank the following for their comments on an earlier draft of this paper: M. Carver, P. Halstead and J. Renfrew. We also thank G. Jones for pointing out, back in 1989, the need for charring experiments on modern grapes, raisins and wine-pressings. 


\section{Grape-pressings from northern Greece}

\section{References}

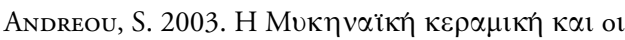

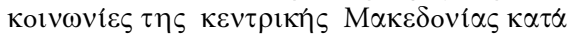

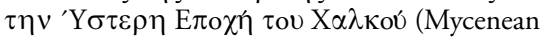
pottery and societies of central Macedonia during the Late Bronze Age), in The Periphery of the Mycenean World (Proceedings of the 2nd Interdisciplinary Colloquium, Lamia 1999). Athens: Greek Ministry of Culture.

Belgiorno, M.R. 2005. dsc.discovery.com/news/ briefs/20050523/wine.html.

Bottema, S. 1982 (1985). Palynological investigations in Greece with special reference to pollen as an indicator of human activity. Palaeohistoria 24: 257-89.

DietLer, M. 2001. Theorizing the feast: rituals of consumption, commensal politics and power in African contexts, in M. Dietler \& B. Hayden (ed.) Feasts: archaeological and ethnographic perspectives on Food, Politics and Power: 65-114. Washington: Smithsonian Institution Press.

FoxhaLL, L. 1998. Snapping up the unconsidered trifles: the use of agricultural residues in ancient Greek and Roman farming. Environmental Archaeology 1: 35-40.

French, D.H. 1971. An experiment in water-sieving. Anatolian Studies 21: 59-64.

Gilman, A. 1981. The development of social stratification in Bronze Age Europe. Current Anthropology 22: 1-8.

Gorny, R.L. 1995. Viticulture in ancient Anatolia, in P.E. McGovern, S.J. Fleming \& S.H. Katz (ed.) The Origins and Ancient History of Wine: 133-74. New York: Gordon \& Breach.

Hamilakis, Y. 1996. Wine, oil and the dialectics of power in Bronze Age Crete: a review of the evidence. Oxford Journal of Archaeology 15: 1-32.

Koukouli-Chrysanthaki, Ch., R. Treuil $\&$ D. Malamidou. 1997. D. Prehistoric settlement Philippoi/Dikili Tash: ten years of excavation. AEMTH 10 $\beta$ : 681-704.

Logothetis, V. 1962. Les Vignes Sauvages (Vitis vinifera L. ssp. silvestris $\mathrm{Gmel}$.) en tant que matériel primitif viticole en Grèce. Scientific Annals of the Arisitotle University Department of Agriculture and Forest: 1-43.

-1974 . Contribution of the grape vine and wine in Greek and Eastern Mediterranean civilization. Scientific Annals of the University of Thessaloniki 17: $1-286$.

Mangafa, M. \& K. Kotsakis. 1996. A new method for the identification of wild and cultivated charred grape seeds. Journal of Archaeological Science 23: 409-18.
Mangafa, M., K. Kotsakis \& S. Andreou. 1998.

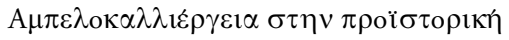
M $\alpha \kappa \varepsilon \delta$ oví $\alpha$ (Viticulture in Prehistoric Macedonia: evidence from Prehistoric Toumba Thessalonikis),

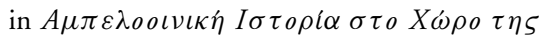

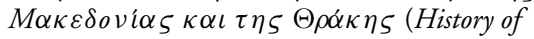
Viticulture and Wine in Macedonia and Thrace): 158-69. Athens: ETBA Publications.

McGovern, P.E. 1995. Introduction, in P.E. McGovern, S.J. Fleming \& S.H. Katz (ed.) The Origins and Ancient History of Wine: ix-xv. New York: Gordon \& Breach.

McGovern, P.E. \& R.H. Mitchel. 1995. The analytical and archaeological challenge of detecting ancient wine: two case studies from the ancient Near East, in P.E. McGovern, S.J. Fleming \& S.H. Katz (ed.) The Origins and Ancient History of Wine: 57-65. New York: Gordon \& Breach.

McGovern, P., D.L. Glusker, L.J. Exner \& M.M. Voight. 1996. Neolithic resinated wine. Nature 381: 480-81.

Olmo, H.P. 1995. The origin and domestication of the Vinifera grape, in P.E. McGovern, S.J. Fleming \& S.H. Katz (ed.) The Origins and Ancient History of Wine: 31-43. New York: Gordon \& Breach.

Palmer, R. 1995. Wine and Viticulture in the Linear A and $B$ texts of the Bronze Age Aegean, in P.E. McGovern, S.J. Fleming \& S.H. Katz (ed.) The Origins and Ancient History of Wine: 269-85. New York: Gordon \& Breach.

Pappa, M., P. Halstead, K. Kotsakis \& D. Urem-Kotsou. 2004. Evidence for large-scale feasting at Late Neolithic Makriyalos, N Greece, in P. Halstead \& J. Barrett (ed.) Food, Cuisine and Society in Prehistoric Greece: 16-44. (Sheffield Studies in Aegean Archaeology 5). Oxford: Oxbow Books.

Renfrew, C. 1972. The Emergence of Civilisation: The Cyclades and the Aegean in the Third Millennium $B C$. London: Methuen.

Renfrew, C., M. Gimbutas \& E. Elster (ed.). 1986. Excavations at Sitagroi. Los Angeles (CA): (Monumenta Archaeologica 13) The Institute of Archaeology.

Renfrew, J. 1972. Appendix V: The plant remains, in P. Warren (ed.) Myrtos: An Early Bronze Age Settlement in Crete, (BSA suppl. 7): 315-17. London: Thames \& Hudson.

-1973. Palaeoethnobotany. The Prehistoric Food Plants of the Near East and Europe. New York: Columbia University Press. 


\section{S.M. Valamoti et al.}

-1995. Palaeoethnobotanical finds of Vitis from Greece, in P.E. McGovern, S.J. Fleming \& S.H. Katz (ed.) The Origins and Ancient History of Wine: 255-67. New York: Gordon \& Breach.

-2003. Grains, seeds, and fruits from Prehistoric Sitagroi, in E.S. Elster \& C. Renfrew (ed.) Prehistoric Sitagroi: Excavations in Northeast Greece, 1968-1970. Volume 2: The Final Report (Monumenta Archaeologica 20): 1-29. Los Angeles: Cotsen Institute of Archaeology.

Rivera Nunez, D. \& M.J. Walker. 1989. A review of palaeobotanical findings of early Vitis in the Mediterranean and of the origins of cultivated grape-vines, with special reference to new pointers to Prehistoric exploitation in the western Mediterranean. Review of Palaeobotany and Palynology 61: 205-37.

Sherratt, A. 1987. Cups That Cheered, in W.H. Waldren \& R.C. Kennard (ed.) Bell Beakers of the Western Mediterranean (British Archaeological Reports SS331 i): 81-114. Oxford: British Archaeological Reports.

-1999. Cash-crops before cash: organic consumables and trade, in C. Gosden \& J. Hather (ed.) The Prehistory of Food, Appetites for change: 13-34. London: Routledge.

Singleton, V.L. 1995. An Enologist's commentary on ancient wines, in P.E. McGovern, S.J. Fleming \& S.H. Katz (ed.) The Origins and Ancient History of Wine: 67-77. New York: Gordon \& Breach.
Stuiver, M. \& P.J. Reimer. 1993. Radiocarbon Calibration Program Rev. 4.3. Radiocarbon 35: 215-30.

Stuiver, M., P.J. Reimer, E. Bard, J.W. Beck, G.S. Burr, K.A. Hughen, B. Kromer, F.G. McCormac, J. van der Plicht \& M. Spurk. 1998. INTCAL98 Radiocarbon Age Calibration, 24 000-0 cal BP. Radiocarbon 40 (3): 1041-83.

Tzedakis, Y. \& H. Martlew (ed.). 1999. Minoans and Myceneans - Flavours of their Time. Athens: Greek Ministry of Culture.

Valamoti, S.-M. 2004. Plants and People in Late Neolithic and Early Bronze Age Northern Greece (British Archaeological Reports IS 1258). Oxford: British Archaeological Reports.

Whittle, A. 1996. Europe in the Neolithic. Cambridge: Cambridge University Press.

Wijmstra, T.A. 1969. Palynology of the first 30 metres of a $120 \mathrm{~m}$ deep section in northern Greece. Acta Bot. Neerl. 18: 511-27.

Wright, J.C. 2004. The Mycenaean Feast. Hesperia 73: 133-78.

Zohary, D. 1995. The domestication of the grapevine Vitis vinifera L. in the Near East, in P.E. McGovern, S.J. Fleming \& S.H. Katz (ed.) The Origins and Ancient History of Wine: 23-30. New York: Gordon \& Breach. 